\title{
Verzuim door RSI-klachten in de Nederlandse beroepsbevolking
}

\author{
M.W. Verheijden • J . Heinrich • S.N.J. van den Bossche • \\ P.G.W. Smulders • B.M. Blatter
}

Samenvatting Er zijn weinig cijfers bekend over het vóórkomen van verzuim door RSI-klachten in de Nederlandse beroepsbevolking. In dit artikel wordt het verzuim door RSI beschreven op basis van een cross-sectioneel vragenlijstonderzoek bij een aselecte steekproef van Nederlandse werknemers. RSI-klachten kwamen voor bij $25 \%$ van de werknemers. Bijna $5 \%$ van de werknemers had in de drie maanden voorafgaand aan het onderzoek verzuimd als gevolg van RSI-klachten. Relatief meer vrouwen dan mannen verzuimden als gevolg van RSI-klachten in de drie maanden voorafgaand aan het onderzoek (respectievelijk 5,1\% en 3,9\%). Ziekmelding als gevolg van RSI-klachten kwam relatief vaak voor bij werknemers met beroepen in de transportsector $(9,2 \%)$ en bij werknemers met ambachtelijke/industriële beroepen $(7,6 \%)$ en relatief weinig bij werknemers in leidinggevende beroepen $(1,6 \%)$. Bedrijfstak was een minder grote risicofactor dan beroep. Geslacht, leeftijd en beroep waren ook in de subgroep van de werknemers met RSI-klachten een risicofactor voor ziekmelding als gevolg van RSI-klachten. Het verdient aanbeveling om in de preventie en behandeling van (verzuim als gevolg van) RSI-klachten aandacht te besteden aan de verschillende risicogroepen.

Keywords RSI-klachten - ziekteverzuim • risicofactoren · beroep $\cdot$ bedrijfstak

M.W. Verheijden $(\bowtie)$

Dr. ir. M.W. Verheijden, drs. J. Heinrich, drs. S.N.J. van den Bossche, dr. P.G.W. Smulders en dr. B.M. Blatter werken bij TNO Kwaliteit van Leven, Hoofddorp. B.M. Blatter werkt ookbij Body@Work, Onderzoekscentrum Bewegen, Arbeid en Gezondheid, TNO Vumc.Correspondentieadres:

Dr. B.M. Blatter, TNO Kwaliteit van Leven, Postbus 718, 2130

AS Hoofddorp.E-mail: B.Blatter@arbeid.tno.nl.

Cross-sectionele surveys laten zien dat de prevalentie van RSI-klachten (ook wel: complaints of arm, neck and/or shoulder; CANS) in de totale Nederlandse beroepsbevolking in 2000, 2002 en 2003 rond de $25 \%$ schommelde. ${ }^{1,2}$ Verschillen tussen de onderzoekspopulaties en tussen de gebruikte definities van RSI-klachten belemmeren vergelijking met andere onderzoeken. ${ }^{3}{ }^{5}$

RSI-klachten kunnen leiden tot ongemak, pijn, beperkingen en participatieproblemen bij werknemers. Toch zullen niet alle RSI-klachten tot chronische klachten of verzuim leiden. Er is echter weinig bekend over de omvang van verzuim als gevolg van RSI-klachten. In 1998 werd door het Rijks Instituut voor Volksgezondheid en Milieu (RIVM) een onderzoek uitgevoerd onder 3664 personen, waarvan 1400 werknemers. Verzuim als gevolg van pijn in nek, schouders, elleboog, pols, of hand die niet werd veroorzaakt door een ongeval of een aangeboren afwijking, kwam voor bij $8 \%$ van de onderzochte werknemers. ${ }^{6}$ Sinds 2003 wordt in de tweejaarlijkse Nationale Enquête Arbeidsomstandigheden (NEA) specifiek aandacht besteed aan RSI-klachten en de gevolgen daarvan. ${ }^{7}$ Omdat in de NEA representatieve gegevens verzameld worden onder een groot aantal werknemers, is de NEA bij uitstek geschikt om inzicht te krijgen in het vóórkomen van RSI-klachten en daaraan gerelateerd verzuim in de Nederlandse beroepsbevolking. Aangezien de definitie van RSI in de NEA gelijk is aan die in de Arbomonitor (gebruikt in veel arboconvenanten), kan de NEA tevens dienen als representatief referentiebestand om de convenantsresultaten tegen af te zetten.

In het huidige onderzoek worden op basis van gegevens uit de NEA dan ook de volgende vragen beantwoord: 
1. Wat is de omvang van verzuim als gevolg van RSIklachten in Nederland? De omvang van verzuim wordt hierbij uitgedrukt als het percentage werknemers dat aangeeft in de drie maanden voorafgaand aan het onderzoek verzuimd te hebben als gevolg van klachten aan nek, schouders, armen, polsen, handen en/of vingers (ooit/nooit).

2. Hoeveel van de mensen met RSI-klachten verzuimen?

3. Zijn er verschillen in verzuim als gevolg van RSIklachten tussen mannen en vrouwen, tussen leeftijdsgroepen, tussen beroepen en tussen bedrijfstakken? En zo ja:

4. Hangen deze verschillen samen met andere (werkgebonden) fysieke en psychosociale risicofactoren?

\section{Methode}

Onderzoeksopzet en populatie

Voor dit onderzoek is gebruikgemaakt van de gegevens van de eerste Nationale Enquête Arbeidsomstandigheden (NEA) in 2003. Deze enquête omvatte onder meer onderwerpen als: dienstverband, psychosociale arbeidsbelasting, fysieke arbeidsbelasting, arbeidsongevallen, en ziekten en aandoeningen. Tevens werd aandacht besteed aan maatregelen tegen RSI, RSI-klachten en verzuim als gevolg van RSI-klachten. Een bespreking van de inhoud en de betrouwbaarheid van de diverse (sub)schalen wordt elders gegeven. ${ }^{7}$ De NEA werd in 2003 verstuurd naar een steekproef van circa 25.000 werknemers. Zelfstandigen waren niet opgenomen in deze steekproef. Aan het onderzoek namen 10.075 werknemers deel (respons: $42 \%$ ). Om te controleren voor mogelijk selectieve nonrespons, zijn de NEA-gegevens gewogen voor geslacht, leeftijd, bedrijfstak en opleidingsniveau.

\section{Uitkomstmaten}

\section{RSI-klachten en verzuim als gevolg van deze klachten}

De module over RSI-klachten bevatte 12 items (schaalscore: 0-36) waarin het vóórkomen van diverse klachten aan nek, schouders, armen, polsen, handen en/of vingers in de voorafgaande drie maanden werd nagevraagd. Een schaalscore van 8 of meer punten werd beschouwd als het (gehad) hebben RSI-klachten. ${ }^{8}$ Respondenten werd bovendien gevraagd naar ziekmelding als gevolg van RSI-klachten en naar het vroegtijdig beëindigen van de werkdag als gevolg van deze klachten (altijd, vaak, soms, nooit).
Geslacht, leeftijd, beroep en bedrijfstak

In de NEA wordt navraag gedaan naar de demografische gegevens van de deelnemers. Leeftijd werd gecategoriseerd in vijf groepen. De vragen naar beroep en bedrijfstak in de NEA werden afgeleid van classificaties van het Centraal Bureau voor de Statistiek. Voor de analyses is gebruikgemaakt van de hoofdgroepen in beroeps- en bedrijfstak die ook in eerdere analyses gebruikt werden.7 Beroep wordt in dit artikel vooral gezien als een weerspiegeling van de taken van werknemers, die mede de blootstelling aan fysieke en psychosociale risicofactoren voor RSI bepalen. Bedrijfstak wordt hierbij meer gezien als een weerspiegeling van de 'cultuur' die in een branche aanwezig is. Vanzelfsprekend bestaat er natuurlijk ook deels overlap tussen beroep en bedrijfstak.

\section{Overige variabelen}

Mogelijke verschillen in het vóórkomen van verzuim door RSI-klachten kunnen wellicht verklaard worden door verschillen in andere factoren dan geslacht, leeftijd, beroep en bedrijfstak. Daarom werden in het huidige onderzoek ook diverse andere factoren bestudeerd, zoals bijvoorbeeld bedrijfsgrootte, kantoorwerk en fysieke en psychosociale arbeidsbelasting. Omdat bedrijven met 100 werknemers of meer vaker RSI-maatregelen treffen dan bedrijven met minder dan 100 werknemers, 2 is dit onderscheid in de huidige analyses opgenomen. Om kantoorwerk te definiëren werden respondenten in zes beroepscategorieën (secretaressen, boekhouders, overige administratieve functies, architecten, statistici en overige vakspecialisten) ingedeeld als kantoorwerker. Respondenten in acht andere categorieën (vertegenwoordigers, verzekeringsagenten, overige commerciële beroepen,

politiepersoneel, overige dienstverlenende functies, docenten hoger onderwijs, leidinggevende functies en overige beroepen) werden ingedeeld als kantoorwerker wanneer zij minimaal drie uur per dag voor hun werk beeldschermwerk verrichtten. De variabelen voor dienstverband, overwerk, werkgerelateerd beeldschermwerk en privé-beeldschermwerk werden gecategoriseerd. Fysieke arbeidsbelasting (buigen of draaien met hoofd/nek, lang achtereen met voorovergebogen of gedraaid hoofd/nek werken, langdurig in dezelfde houding werken, armen geheven houden en repeterende bewegingen in de bovenste extremiteiten) en psychosociale arbeidsbelasting (autonomie, werktempo/ tijdsdruk en emotionele belasting) werden gecategoriseerd zoals ook voor eerdere rapportages over de NEA. ${ }^{7}$ 
Analyses

De prevalentie van verzuim als gevolg van RSI-klachten ( $\%$ ooit in de afgelopen drie maanden) werd berekend voor de totale onderzoeksgroep en voor de subgroep met RSI-klachten in de drie maanden voorafgaand aan het onderzoek. De gegevens werden uitgesplitst naar geslacht, leeftijd, beroep en bedrijfstak. Om de verschillen in prevalentie voor elkaar en voor andere risicofactoren te corrigeren, werden logistische regressieanalyses uitgevoerd, waarbij het optreden van verzuim als gevolg van RSI-klachten de afhankelijke variabele was. In dit artikel worden ruwe en gecorrigeerde odds ratio's (OR) en de bijbehorende 95\%-BI (betrouwbaarheidsintervallen) gepresenteerd. Een OR is een maat voor de sterkte van een effect. Een OR groter dan 1 betekent dat er in een bepaalde categorie een groter risico is dan in de referentiecategorie. Wanneer het 95\%-BI van een OR het getal 1 omvat, betekent dit dat er geen sprake is van een statistisch significant verband. Als referentiecategorie voor beroep en bedrijfstak werd gekozen voor de categorieën met de laagste prevalentie van verzuim als gevolg van RSI-klachten (leidinggevende beroepen en de zakelijke dienstverlening).

1. RSI-klachten kwamen in 2003 voor bij $25 \%$ van de beroepsbevolking. In bijna $5 \%$ van de beroepsbevolking leidden deze klachten tot verzuim.

2. Er waren grote verschillen tussen beroepen en bedrijfstakken in het vóórkomen van verzuim als gevolg van RSI-klachten. Vooral in transportberoepen en in ambachtelijke/industriële beroepen kwam dit verzuim veel voor.

3. Verschillen in het vóórkomen van verzuim als gevolg van RSI-klachten tussen beroepen en bedrijfstakken werden vooral verklaard door verschillen in fysieke en psychosociale arbeidsbelasting.

Vanwege missende waarden in de dataset werden de logistische regressieanalyses voor de totale onderzoeksgroep uitgevoerd met 7957 respondenten. De analyses werden herhaald voor de subgroep van respondenten met RSI-klachten $(n=1981)$.

\section{Resultaten}

Populatiekenmerken

Van de respondenten was 57\% man; de gemiddelde leeftijd was 38 (SD 11) jaar. Het merendeel van de respondenten $(84 \%)$ had een vast dienstverband. De gemiddelde omvang van het dienstverband was 31,6 uur per week. Bijna iedereen (91\%) beoordeelde de eigen gezondheid over het algemeen genomen als goed tot uitstekend.

RSI-klachten en verzuim als gevolg van RSI-klachten in de Nederlandse beroepsbevolking

RSI-klachten kwamen voor bij 25,4\% van de respondenten $(n=2557)$. RSI-klachten kwamen vaker voor bij vrouwen (29\%) dan bij mannen (22\%). 18,6\% van de werknemers met RSI-klachten had zich in de drie maanden voorafgaand aan het onderzoek ziek gemeld als gevolg van deze klachten; dit is $4,7 \%$ van de totale onderzoeksgroep. Daarnaast had 1,3\% van de respondenten van de totale onderzoeksgroep in de drie maanden voorafgaand aan het onderzoek één of meerdere werkdagen vroegtijdig beëindigd als gevolg van RSI-klachten $(5,1 \%$ van de werknemers met klachten).

In tabel 1 wordt een overzicht gegeven van verzuim als gevolg van RSI-klachten in de totale onderzoeksgroep, uitgesplitst naar geslacht, leeftijd, beroep en bedrijfstak. Vrouwen meldden zich vaker ziek als gevolg van RSIklachten dan mannen (respectievelijk $5,1 \%$ en 3,9\%). Ook kwam ziekmelding als gevolg van RSI-klachten vaker voor bij oudere werknemers dan bij jongere werknemers. Deze verschillen worden weerspiegeld in de ongecorrigeerde OR's. De effecten van geslacht en leeftijd werden sterker wanneer gecorrigeerd werd voor andere factoren. Het verhoogde risico op verzuim als gevolg van RSI-klachten van vrouwen ten opzichte van mannen $(\mathrm{OR}=1,33)$ steeg bijvoorbeeld tot een $\mathrm{OR}$ van 1,86 wanneer gecorrigeerd werd voor leeftijd en beroep. In de analyses waarin bovendien gecorrigeerd werd voor fysieke en psychosociale arbeidsbelasting, was het risico op verzuim als gevolg van RSI-klachten voor vrouwen zelfs 2,1 keer zo groot als voor mannen. Ook in bepaalde beroepsgroepen werd relatief veel ziekteverzuim als gevolg van RSI-klachten gevonden. Dit was bijvoorbeeld in transportberoepen $(9,2 \%)$ en in ambachtelijke of industriële beroepen $(7,6 \%)$. Deze hoge prevalenties werden niet verklaard door verschillen in geslacht of leeftijd tussen de beroepen of bedrijfstakken, maar wel voor een groot deel door fysieke en psychische risicofactoren voor RSI-klachten. Ten slotte werd veel ziekteverzuim als gevolg van RSI-klachten gevonden in de energie- en waterleidingbedrijven $(9,3 \%)$ en in de bouwnijverheid $(7,6 \%)$. Deze hoge prevalenties werden weerspiegeld in de verhoogde ongecorrigeerde OR's. Ook deze prevalenties werden niet verklaard door verschillen in geslacht of leeftijd, maar wel door verschillen in fysieke en psychosociale risicofactoren voor RSI-klachten. 
Tabel 1 Verzuim als gevolg van RSI-klachten in de afgelopen drie maanden onder Nederlandse werknemers naar geslacht, leeftijd, beroep en bedrijfstak, $n=7957$. Significante effecten zijn vet weergegeven.

\begin{tabular}{|c|c|c|c|c|c|c|c|}
\hline & \multirow[t]{2}{*}{ Prevalentie verzuim* } & \multicolumn{2}{|c|}{$\begin{array}{r}\text { Ongecorrigeerd } \\
\text { effect }\end{array}$} & \multicolumn{2}{|c|}{$\begin{array}{r}\text { Effect gecorrigeerd } \\
\text { voor leeftijd, } \\
\text { geslacht en beroep } \\
\text { of bedrijfstak }\end{array}$} & \multicolumn{2}{|c|}{$\begin{array}{r}\text { Effect tevens } \\
\text { gecorrigeerd voor } \\
\text { fysieke en } \\
\text { psychosociale } \\
\text { arbeidsbelasting }\end{array}$} \\
\hline & & OR & $95 \%-\mathrm{BI} * *$ & OR & $95 \%-\mathrm{BI} * *$ & OR & $95 \%-\mathrm{BI} * *$ \\
\hline \multicolumn{8}{|l|}{ Geslacht } \\
\hline $\operatorname{man}(n=4681)$ & $3,9 \%$ & - & & $-\mathrm{a}$ & & $-\mathrm{c}$ & \\
\hline vrouw $(\mathrm{n}=3276)$ & $5,1 \%$ & 1,33 & $1,08-1,65$ & 1,86 & $1,43-2,41$ & 2,10 & $1,55-2,85$ \\
\hline \multicolumn{8}{|l|}{ Leeftijd } \\
\hline $15-24$ jaar $(\mathrm{n}=1209)$ & $3,4 \%$ & - & & $-\mathrm{a}$ & & - & \\
\hline $25-34$ jaar $(\mathrm{n}=2297)$ & $4,3 \%$ & 1,27 & $0,88-1,84$ & 1,38 & $0,94-2,00$ & 1,91 & $1,28-2,86$ \\
\hline $35-44$ jaar $(\mathrm{n}=2216)$ & $3,8 \%$ & 1,11 & $0,76-1,62$ & 1,21 & $0,82-1,78$ & 1,75 & $1,16-2,65$ \\
\hline $45-54$ jaar $(n=1723)$ & $5,5 \%$ & 1,64 & $1,13-2,39$ & 1,78 & $1,21-2,60$ & 2,38 & $1,57-3,62$ \\
\hline 55-64 jaar $(\mathrm{n}=512)$ & $6,1 \%$ & 1,82 & $1,13-2,94$ & 2,08 & $1,28-3,38$ & 3,20 & $1,88-5,44$ \\
\hline \multicolumn{8}{|l|}{ Beroep } \\
\hline leidinggevend $(\mathrm{n}=640)$ & $1,6 \%$ & - & & $-\mathrm{a}$ & & $-\mathrm{c}$ & \\
\hline transport $(\mathrm{n}=305)$ & $9,2 \%$ & 6,42 & $3,07-13,44$ & 7,38 & $3,51-15,51$ & 3,58 & $1,56-8,21$ \\
\hline administratief $(\mathrm{n}=1142)$ & $3,7 \%$ & 2,43 & $1,21-4,89$ & 1,87 & $0,92-3,81$ & 1,64 & $0,78-3,43$ \\
\hline commercieel $(\mathrm{n}=1296)$ & $4,3 \%$ & 2,86 & $1,45-5,66$ & 2,69 & $1,35-5,37$ & 2,04 & $0,98-4,23$ \\
\hline dienstverlenend $(\mathrm{n}=835)$ & $5,0 \%$ & 3,37 & $1,67-6,79$ & 3,14 & $1,55-6,36$ & 2,10 & $1,00-4,41$ \\
\hline gezondheidszorg en hulpverlening $(\mathrm{n}=748)$ & $4,4 \%$ & 2,90 & $1,41-5,95$ & 2,13 & $1,02-4,44$ & 0,99 & $0,44-2,22$ \\
\hline leerkrachten/docenten $(\mathrm{n}=290)$ & $3,4 \%$ & 2,36 & $0,98-5,71$ & 1,84 & $0,76-4,46$ & 1,22 & $0,48-3,14$ \\
\hline vakspecialisten $(\mathrm{n}=927)$ & $2,4 \%$ & 1,57 & $0,74-3,35$ & 1,71 & $0,80-3,65$ & 1,68 & $0,77-3,67$ \\
\hline $\operatorname{agrarisch}(\mathrm{n}=131)$ & $5,3 \%$ & 3,65 & $1,37-9,74$ & 4,13 & $1,54-11,06$ & 2,13 & $0,73-6,18$ \\
\hline ambachtelijk/industrieel $(\mathrm{n}=958)$ & $7,6 \%$ & 5,21 & $2,66-10,21$ & 5,80 & $2,95-11,39$ & 2,69 & $1,25-5,78$ \\
\hline overig $(\mathrm{n}=685)$ & $4,1 \%$ & 2,70 & $1,30-5,63$ & 2,45 & $1,17-5,12$ & 1,84 & $0,86-3,93$ \\
\hline \multicolumn{8}{|l|}{ Bedrijfstak } \\
\hline zakelijke dienstverlening $(\mathrm{n}=953)$ & $2,6 \%$ & - & & $-b$ & & $-d$ & \\
\hline bouwnijverheid ( $\mathrm{n}=423)$ & $7,6 \%$ & 3,09 & $1,80-5,29$ & 3,36 & $1,94-5,81$ & 1,24 & $0,67-2,32$ \\
\hline handel $(\mathrm{n}=1263)$ & $4,2 \%$ & 1,64 & $1,01-2,67$ & 1,61 & $0,99-2,62$ & 0,93 & $0,54-1,60$ \\
\hline vervoer en communicatie $(\mathrm{n}=452)$ & $6,9 \%$ & 2,81 & $1,63-4,82$ & 2,88 & $1,67-4,97$ & 1,33 & $0,74-2,42$ \\
\hline financiële instellingen $(\mathrm{n}=542)$ & $4,2 \%$ & 1,71 & $0,96-3,04$ & 1,62 & $0,91-2,89$ & 1,42 & $0,79-2,57$ \\
\hline industrie $(\mathrm{n}=1176)$ & $3,9 \%$ & 1,53 & $0,93-2,52$ & 1,57 & $0,95-2,60$ & 0,92 & $0,54-1,60$ \\
\hline onderwijs $(n=412)$ & $3,4 \%$ & 1,29 & $0,66-2,53$ & 1,07 & $0,54-2,11$ & 0,68 & $0,33-1,41$ \\
\hline gezondheids- en welzijnszorg $(\mathrm{n}=1191)$ & $4,5 \%$ & 1,80 & $1,11-2,92$ & 1,44 & $0,88-2,36$ & 0,67 & $0,38-1,19$ \\
\hline openbaar bestuur/overheid $(\mathrm{n}=731)$ & $4,1 \%$ & 1,64 & $0,96-2,82$ & 1,54 & $0,89-2,65$ & 1,31 & $0,75-2,30$ \\
\hline overige dienstverlening $(\mathrm{n}=274)$ & $5,8 \%$ & 2,42 & $1,27-4,58$ & 2,26 & $1,19-4,30$ & 1,58 & $0,80-3,11$ \\
\hline landbouw, bosbouw en visserij $(\mathrm{n}=190)$ & $4,7 \%$ & 1,80 & $0,82-3,98$ & 1,92 & $0,87-4,25$ & 0,90 & $0,39-2,10$ \\
\hline energie- en waterleidingbedrijven $(n=54)$ & $9,3 \%$ & 3,86 & $1,41-10.57$ & 4,06 & $1,47-11,16$ & 2,80 & $0,96-8,16$ \\
\hline horeca $(n=296)$ & $4,4 \%$ & 1,72 & $0,87-3,42$ & 1,83 & $0,91-3,67$ & 0,77 & $0,75-1,22$ \\
\hline
\end{tabular}

${ }^{*}$ Verzuim $=$ ziekmelding in de drie maanden voorafgaand aan het onderzoek als gevolg van klachten aan nek, schouders, armen, polsen, handen en/of vingers.

${ }^{* *} \mathrm{BI}=$ betrouwbaarheidsinterval.

aOdds ratio's wanneer geslacht, leeftijd en beroep in het model waren opgenomen.

bOdds ratio's wanneer geslacht, leeftijd en bedrijfstak in het model waren opgenomen

cOdds ratio's wanneer geslacht, leeftijd, beroep, bedrijfsgrootte, omvang dienstverband en overwerk, kantoorwerk, duur beeldschermwerk per dag (werk en privé), fysieke arbeidsbelasting en psychosociale arbeidsbelasting in het model waren opgenomen.

dOdds ratio's wanneer geslacht, leeftijd, bedrijfstak, bedrijfsgrootte, omvang dienstverband en overwerk, kantoorwerk, duur beeldschermwerk per dag (werk en privé), fysieke arbeidsbelasting en psychosociale arbeidsbelasting in het model waren opgenomen. 
Verzuim als gevolg van RSI-klachten in de groep werknemers met RSI-klachten

In tegenstelling tot in de totale onderzoekspopulatie (tabel 1), was het ziekteverzuim binnen de groep werknemers met klachten vergelijkbaar tussen vrouwen $(17 \%)$ en mannen (18\%) (tabel 2). Dit wordt weerspiegeld in de ongecorrigeerde OR van 0,95. Gecorrigeerd voor andere risicofactoren, hadden vrouwen echter ook in de groep werknemers met RSI-klachten een statistisch significant hoger risico op ziekmelding dan mannen $(\mathrm{OR}=1,39)$. Dit betekent dat vrouwen met RSI-klachten vaker verzuimen dan mannen met RSI-klachten. Ziekteverzuim kwam in de totale onderzoekspopulatie vaker voor bij oudere werknemers (tabel 1). Binnen de groep werknemers met RSI-klachten, kwam ziekmelding juist relatief veel voor bij jongere werknemers (25-34 jaar), ook na correctie voor andere factoren (tabel 2). Dit lijkt erop te duiden dat in de groep tussen 25 en 34 jaar weliswaar relatief minder klachten voorkomen, maar dat men eerder verzuimt dan oudere werknemers als men eenmaal klachten heeft. De effecten van geslacht en leeftijd in de groep werknemers met RSI-klachten (tabel 1) waren overigens kleiner dan in de totale onderzoeksgroep (tabel 2). Ook in de subgroep werknemers met RSI-klachten kwam ziekteverzuim als gevolg van deze klachten relatief vaak voor in transportberoepen $(33 \%$ van de werknemers verzuimde in de drie maanden voorafgaand aan het onderzoek als gevolg van RSI-klachten) en in ambachtelijke of industriële beroepen (23\%). De energie- en waterleidingbedrijven (29\%) en de bouwnijverheid $(27 \%)$ waren opnieuw de bedrijfstakken waarin verzuim als gevolg van RSI-klachten het vaakst voorkwam. Hierbij moet in acht worden genomen dat de gegevens over de energie- en waterleidingbedrijven gebaseerd zijn op een klein aantal werknemers. Ook in de groep werknemers met RSI-klachten bleken de verschillen tussen beroepen en bedrijfstakken grotendeels verklaard te kunnen worden door verschillen in fysieke en psychosociale risicofactoren.

\section{Discussie}

RSI-klachten kwamen voor bij 25\% van de beroepsbevolking en leidden in bijna 5\% van de beroepsbevolking tot verzuim. Vooral vrouwen bleken een verhoogd risico op ziekmelding als gevolg van RSI-klachten te hebben. Er werden aanmerkelijke verschillen in prevalentie van ziekmelding als gevolg van RSI-klachten gevonden tussen beroepen en bedrijfstakken. Deze verschillen werden niet zozeer verklaard door verschillen in leeftijd en geslacht, maar wel door verschillen in fysieke en psychosociale arbeidsbelasting.

Het percentage werknemers dat verzuimde in de drie maanden voorafgaand aan het onderzoek als gevolg van RSI-klachten (5\%) ligt iets lager dan de $8 \%$ door klachten aan nek, schouders, armen, ellebogen, polsen en handen die eerder gerapporteerd werd,6 maar laatstgenoemd cijfer had dan ook betrekking op een heel jaar. Tot nu toe was monitoring van trends in de prevalentie van RSIklachten en daaraan gerelateerd verzuim slechts in zeer beperkte mate mogelijk. Het Centraal Bureau voor de Statistiek heeft alleen voor de periode van 1997 tot 2000 gegevens verzameld over de prevalentie van RSI-klachten $(16-23 \%)$ en daaraan gerelateerd verzuim (3-4\%) en hanteerde tevens een definitie voor RSI waarbij blootstelling aan fysieke risicofactoren als voorwaarde gesteld werd. ${ }^{9}$ Vervolgmetingen van de NEA maken monitoring van trends in de toekomst wel mogelijk. Net als in diverse andere onderzoeken, wordt in de NEA gebruikgemaakt van cross-sectionele zelfrapportage over klachten en verzuim. Vanzelfsprekend is hieraan het nadeel verbonden dat veranderingen binnen personen niet gemeten worden. Eén van de kanttekeningen die bij het huidige onderzoek geplaatst moeten worden, is het feit dat op basis van de gegevens uit de NEA die gebaseerd zijn op de RSIdefinities zoals deze gebruikt worden in de Arbomonitor geen inzicht kan worden verkregen in de verzuimfrequentie en verzuimduur als gevolg van RSI-klachten. In de NEA is ook een andere definitie van RSI-klachten opgenomen (hierbij wordt de oorzaak van het laatste verzuimgeval nagevraagd). Op basis van deze definitie kan inzicht in verzuimduur verkregen worden. ${ }^{16}$ Ten tweede zijn zelfstandigen in de NEA buiten beschouwing gelaten en zijn gegevens over enkele beroepen en bedrijfstakken (vooral de energie- en waterleidingbedrijven, $n=54$ ) gebaseerd op een zeer beperkt aantal werknemers. Gegevens over deze beroepen en bedrijfstakken werden ter indicatie wel gepresenteerd, maar moeten met enige voorzichtigheid geïnterpreteerd te worden.

Het risico op ziekmelding als gevolg van RSI-klachten in de Nederlandse beroepsbevolking was hoger bij vrouwen dan bij mannen. Er zijn in de literatuur aanwijzingen dat ook verzuim als gevolg van RSI-klachten vaker voorkomt bij vrouwen dan bij mannen; een cohort van werknemers met circa vier weken verzuim als gevolg van RSIklachten bevatte $80 \%$ vrouwen. $^{10}$ In het eerder genoemde RIVM-onderzoek werd echter geen verschil gezien. ${ }^{6}$ Verschillen worden mogelijk veroorzaakt doordat vrouwen ook een hogere prevalentie van RSI-klachten hebben. ${ }^{1,11}$ Hiervoor zijn drie mogelijke verklaringen bekend. $^{12}$ Ten eerste is het mogelijk dat vrouwen (pijn) klachten anders ervaren en rapporteren dan mannen. Een tweede mogelijkheid is dat verschillen in prevalentie 
Tabel 2 Verzuim als gevolg van RSI-klachten in de afgelopen drie maanden onder Nederlandse werknemersmet RSI-klachten naar geslacht, leeftijd, beroep en bedrijfstak,n $=1981$. Significante effecten zijn vet weergegeven.

\begin{tabular}{|c|c|c|c|}
\hline \multirow[t]{2}{*}{ Prevalentie verzuim* } & $\begin{array}{l}\text { Ongecorrigeerd } \\
\text { effect }\end{array}$ & $\begin{array}{l}\text { Effect gecorrigeerd } \\
\text { voor leeftijd, } \\
\text { geslacht en beroep } \\
\text { of bedrijfstak }\end{array}$ & $\begin{array}{l}\text { Effect tevens } \\
\text { gecorrigeerd voor } \\
\text { fysieke en } \\
\text { psychosociale } \\
\text { arbeidsbelasting }\end{array}$ \\
\hline & $95 \%-\mathrm{BI} * *$ & $95 \%-B I * *$ & $95 \%-\mathrm{BI} * *$ \\
\hline
\end{tabular}

\begin{tabular}{|c|c|c|c|c|c|c|c|}
\hline Geslacht & & & & & & & \\
\hline $\operatorname{man}(\mathrm{n}=1009)$ & $18 \%$ & - & & $-\mathrm{a}$ & & $-\mathrm{c}$ & \\
\hline vrouw $(\mathrm{n}=972)$ & $17 \%$ & 0,95 & $0,75-1,19$ & 1,11 & $0,83-1,47$ & 1,39 & $1,01-1,93$ \\
\hline Leeftijd & & & & & & & \\
\hline $15-24$ jaar $(n=269)$ & $15 \%$ & - & & $-\mathrm{a}$ & & $-\mathrm{c}$ & \\
\hline 25-34 jaar $(n=487)$ & $20 \%$ & 1,41 & $0,94-2,09$ & 1,51 & $1,01-2,27$ & 1,74 & $1,12-2,71$ \\
\hline $35-44$ jaar $(\mathrm{n}=542)$ & $16 \%$ & 1,01 & $0,67-1,51$ & 1,09 & $0,72-1,65$ & 1,33 & $0,84-2,09$ \\
\hline $45-54$ jaar $(\mathrm{n}=510)$ & $19 \%$ & 1,26 & $0,85-1,88$ & 1,31 & $0,87-1,98$ & 1,52 & $0,96-2,40$ \\
\hline $55-64$ jaar $(n=173)$ & $18 \%$ & 1,21 & $0,73-2,01$ & 1,21 & $0,72-2,04$ & 1,52 & $0,86-2,71$ \\
\hline Beroep & & & & & & & \\
\hline leidinggevend $(\mathrm{n}=126)$ & $8 \%$ & - & & $-\mathrm{a}$ & & $-\mathrm{c}$ & \\
\hline transport $(\mathrm{n}=84)$ & $33 \%$ & 5,87 & $2,66-12,96$ & 6,04 & $2,73-13,38$ & 3,46 & $1,42-8,45$ \\
\hline administratief $(\mathrm{n}=323)$ & $13 \%$ & 1,74 & $0,84-3,60$ & 1,67 & $0,80-3,50$ & 1,73 & $0,79-3,79$ \\
\hline commercieel $(\mathrm{n}=280)$ & $20 \%$ & 2,91 & $1,43-5,94$ & 2,87 & $1,39-5,92$ & 2,40 & $1,11-5,17$ \\
\hline dienstverlenend $(\mathrm{n}=228)$ & $18 \%$ & 2,64 & $1,27-5,49$ & 2,66 & $1,27-5,56$ & 2,06 & $0,94-4,51$ \\
\hline gezondheidszorg en hulpverlening $(\mathrm{n}=186)$ & $18 \%$ & 2,49 & $1,18-5,29$ & 2,39 & $1,10-5,17$ & 1,32 & $0,56-3,10$ \\
\hline leerkrachten/docenten $(n=64)$ & $16 \%$ & 2,25 & $0,89-5,69$ & 2,08 & $0,81-5,32$ & 1,47 & $0,55-3,97$ \\
\hline vakspecialisten $(\mathrm{n}=189)$ & $12 \%$ & 1,56 & $0,71-3,43$ & 1,56 & $0,71-3,43$ & 1,55 & $0,68-3,54$ \\
\hline $\operatorname{agrarisch}(\mathrm{n}=37)$ & $19 \%$ & 2,81 & $0,99-7,99$ & 2,90 & $1,02-8,27$ & 2,15 & $0,32-6,21$ \\
\hline ambachtelijk/industrieel $(\mathrm{n}=314)$ & $23 \%$ & 3,51 & $1,74-7,07$ & 3,60 & $1,78-7,27$ & 2,27 & $1,02-5,08$ \\
\hline overig $(\mathrm{n}=150)$ & $18 \%$ & 2,67 & $1,24-5,76$ & 2,51 & $1,16-5,45$ & 1,92 & $0,86-4,32$ \\
\hline Bedrijfstak & & & & & & & \\
\hline zakelijke dienstverlening $(\mathrm{n}=191)$ & $13 \%$ & - & & $-b$ & & $-\mathrm{d}$ & \\
\hline bouwnijverheid $(\mathrm{n}=118)$ & $27 \%$ & 2,50 & $1,39-4,50$ & 2,57 & $1,41-4,67$ & 1,16 & $0,59-2,29$ \\
\hline handel $(\mathrm{n}=303)$ & $17 \%$ & 1,42 & $0,85-2,39$ & 1,45 & $0,86-2,44$ & 0,91 & $0,50-1,63$ \\
\hline vervoer en communicatie $(n=123)$ & $25 \%$ & 2,30 & $1,28-4,14$ & 2,35 & $1,30-4,25$ & 1,25 & $0,65-2,40$ \\
\hline financiële instellingen $(n=133)$ & $17 \%$ & 1,45 & $0,78-2,68$ & 1,46 & $0,79-2,70$ & 1,36 & $0,71-2,58$ \\
\hline industrie $(\mathrm{n}=313)$ & $15 \%$ & 1,16 & $0,69-1,97$ & 1,20 & $0,71-2,05$ & 0,72 & $0,40-1,29$ \\
\hline onderwijs $(\mathrm{n}=94)$ & $15 \%$ & 1,14 & $0,56-2,33$ & 1,11 & $0,54-2,29$ & 0,68 & $0,31-1,48$ \\
\hline gezondheids- en welzijnszorg $(\mathrm{n}=325)$ & $17 \%$ & 1,36 & $0,81-2,27$ & 1,38 & $0,81-2,33$ & 0,68 & $0,37-1,26$ \\
\hline openbaar bestuur/overheid $(\mathrm{n}=161)$ & $19 \%$ & 1,57 & $0,88-2,81$ & 1,57 & $0,88-2,81$ & 1,28 & $0,70-2,35$ \\
\hline overige dienstverlening $(\mathrm{n}=74)$ & $22 \%$ & 1,95 & $0,97-3,89$ & 2,03 & $1,01-4,07$ & 1,42 & $0,68-2,99$ \\
\hline landbouw, bosbouw en visserij $(n=48)$ & $18 \%$ & 1,48 & $0,63-3,47$ & 1,54 & $0,65-3,60$ & 0,94 & $0,38-2,38$ \\
\hline energie- en waterleidingbedrijven $(\mathrm{n}=17)$ & $29 \%$ & 2,91 & $0,94-9,04$ & 3,24 & $1,04-10,11$ & 2,11 & $0,63-7,03$ \\
\hline horeca $(\mathrm{n}=79)$ & $17 \%$ & 1,32 & $0,63-2,74$ & 1,34 & $0,64-2,81$ & 0,68 & $0,30-1,56$ \\
\hline
\end{tabular}

${ }^{*}$ Verzuim $=$ ziekmelding in de drie maanden voorafgaand aan het onderzoek als gevolg van klachten aan nek, schouders, armen, polsen, handen en/of vingers.

${ }^{* *} \mathrm{BI}=$ betrouwbaarheidsinterval.

aOdds ratio's wanneer geslacht, leeftijd en beroep in het model waren opgenomen.

bOdds ratio's wanneer geslacht, leeftijd en bedrijfstak in het model waren opgenomen.

cOdds ratio's waneer geslacht, leeftijd, beroep, bedrijfsgrootte, omvang dienstverband en overwerk, kantoorwerk, duur beeldschermwerk per dag (werk en privé), fysieke arbeidsbelasting en psychosociale arbeidsbelasting in het model waren opgenomen.

dOdds ratio's wanneer geslacht, leeftijd, bedrijfstak, bedrijfsgrootte, omvang dienstverband en overwerk, kantoorwerk, duur beeldschermwerk per dag (werk en privé), fysieke arbeidsbelasting en psychosociale arbeidsbelasting in het model waren opgenomen. 
verklaard worden door verschillen in blootstelling aan risicofactoren, zelfs wanneer mannen en vrouwen hetzelfde beroep hebben. De laatste verklaring uit de literatuur is dat risicofactoren verschillende effecten kunnen hebben bij mannen en vrouwen. Naast verschillen in de prevalentie van RSI-klachten spelen mogelijk ook andere factoren zoals de ernst van de klachten of verzuimgedrag een rol. In het huidige onderzoek werd namelijk ook in de analyses waarin alleen gekeken werd naar werknemers met RSI-klachten, een verhoogd risico op ziekmelding gevonden bij vrouwen.

De rol van kracht, repeterend werk en (in mindere mate) beeldschermwerk bij RSI-klachten ${ }^{13-15}$ houdt in dat er tussen beroepen en bedrijfstakken verschillen zijn in RSI-klachten. In het huidige onderzoek werd dan ook nadrukkelijk gekeken naar het effect van beroep en bedrijfstak. Beide factoren bleken een rol te spelen bij ziekteverzuim als gevolg van RSI-klachten. De effecten van beroep waren over het geheel genomen sterker dan die van bedrijfstak: wanneer beroep en bedrijfstak gelijktijdig in één model werden opgenomen (ondanks mogelijke overlap), bleek alleen beroep een risicofactor voor verzuim als gevolg van RSI-klachten. Tussen beroepen en bedrijfstakken bestaan verschillen die niet alleen het risico op het ontstaan van klachten bepalen, maar ook (mede) bepalen of het voor werknemers met RSI-klachten mogelijk is om door te werken. In sommige gevallen zal de aanwezigheid van RSI-klachten vrijwel direct leiden tot verzuim, terwijl in andere beroepen (een deel van) de werkzaamheden nog uitgevoerd kunnen worden, zodat ziekteverzuim uitblijft.

Kort gezegd kwamen RSI-klachten tijdens de drie maanden voorafgaand aan het onderzoek voor bij een kwart van de Nederlandse beroepsbevolking. $6 \%$ van de Nederlandse beroepsbevolking moest de werkdag vroegtijdig beëindigen of zich ziekmelden als gevolg van RSIklachten. RSI-klachten zijn hiermee een belangrijke factor die de arbeidsproductiviteit beïnvloedt. In de preventie en behandeling van RSI-klachten dient speciale aandacht besteed te worden aan vrouwen, oudere werknemers en werknemers met transportberoepen of ambachtelijke/industriële beroepen. Qua sectoren verdient vooral de bouwnijverheid speciale aandacht.

\section{DANKWOORD}

De onderzoekers bedanken graag Ernest de Vroome van TNO Kwaliteit van Leven voor zijn advies over de statistische analyses. Financiële steun voor de uitvoering van het hier gerapporteerde onderzoek naar het vóórkomen van RSI-klachten en daaraan gerelateerd verzuim werd in het kader van het Doelfinancieringsprogramma
Arbeid, Deelprogramma Monitoring aan TNO beschikbaar gesteld door het ministerie van OC\&W voor onderzoek op het beleidsterrein van het ministerie van SZW. De NEA wordt gecoördineerd door TNO en de dataverzameling werd in 2003 uitgevoerd door Intomart GfK. Belangenconflicten: geen gemeld

\section{Literatuur}

Heinrich J, Blatter BM. RSI-klachten in de Nederlandse beroepsbevolking. Trends, risicofactoren en verklaringen. TSG 2005; 83: $16-24$

Heinrich J, Blatter BM, Bossche SNJ van den, et al. RSImaatregelen in de Nederlandse beroepsbevolking. Tijdschr Bedrijfs Verzekeringsgeneeskd 2005; 3: 69-75.

Kraker H de, Blatter BM. Prevalentiecijfers van RSI-klachten en het vóórkomen van risicofactoren in 15 Europese landen. TSG 2005; $1: 8-15$.

Gezondheidsraad. RSI. Den Haag: Gezondheidsraad, 2000. Publicatienummer $2000 / 22$.

Houtman I, Andries F, Hupkens C. Kerncijfers gezondheid, productiviteit en sociale zekerheid. In: Houtman ILD, Smulders PGW, Klein Hesselink DJ (red.), Trends in arbeid 2004. Hoofddorp: TNO Arbeid, 2004, pp. 67-93.

Blatter BM, Heuvel SG van den, Bongers PM, et al. De omvang van verzuim en arbeidsongeschiktheid door RSI. Den Haag: ministerie van SZW, 2001.

Bossche SNJ van den, Smulders PGW. De Nationale Enquête Arbeidsomstandigheden 2003. Methodologie en globale resultaten. Hoofddorp: TNO Arbeid, 2004.

Broersen JPJ, Fortuin RJ, Veldhoven M van, et al. Monitor Arboconvenanten: kengetallen en grenswaarden. Tijdschr Bedrijfs Verzekeringsgeneeskd 2004; 12: 100-104.

Otten F, Bongers PM, Houtman I. De kans op RSI in Nederland; gegevens uit het Permanent Onderzoek Leefsituatie, 1997, maandbericht gezondheidsstatistiek. Heerlen: Centraal Bureau voor de Statistiek, 1998.

Blatter B, Heuvel SG van den, Vroome EMM de, Bongers PM. Behandeling en sociaal-medische begeleiding bij verzuim door klachten van arm, nek of schouder (RSI). Tijdschr Bedrijfs Verzekeringsgeneeskd 2004; 12: 293-299.

Yassi A, Sprout J, Tate R. Upper limb repetitive strain injuries in Manitoba. Am J Ind Med 1996; 30: 461-472.

Hooftman WE, Beek AJ van der, Bongers PM, et al. Gender differences in self-reported physical and psychosocial exposures in jobs with both female and male workers. J Occup Environ Med 2005; 47: 244-252.

Bongers PM, Vet HCW de, Blatter BM. RSI: vóórkomen, ontstaan, therapie en preventie. Ned Tijdschr Geneeskd 2002; 146: 1971-1975.

Jensen C. Development of neck and hand-wrist symptoms in relation to duration of computer use at work. Scand J Work Environ Health 2003; 29: 197-205.

National Research Council and Institute of Medicine. Musculoskeletal disorders and the workplace: low back and upper extremities. Washington, DC: National Academy Press, 2001.

Blatter B, Houtman I, Bossche S van den, et al. Gezondheidsschade en kosten als gevolg van RSI en psychosociale arbeidsbelasting in Nederland. Den Haag: ministerie van SZW, 2005. 